\title{
Impacts of the COVID-19 Pandemic on Active Travel Mode Choice in Bangladesh: A Study from the Perspective of Sustainability and New Normal Situation
}

\author{
Niaz Mahmud Zafri ${ }^{1, *}{ }^{\mathbb{D}}$, Asif Khan ${ }^{1}$, Shaila Jamal ${ }^{2} \mathbb{1}$ and Bhuiyan Monwar Alam ${ }^{3}$ \\ 1 Department of Urban and Regional Planning, Bangladesh University of Engineering and Technology (BUET), \\ Dhaka 1000, Bangladesh; asif@urp.buet.ac.bd \\ 2 School of Earth, Environment \& Society, McMaster University, Hamilton, ON L8S 4L8, Canada; \\ jamals16@mcmaster.ca \\ 3 Department of Geography \& Planning, University of Toledo, Toledo, OH 43606, USA; \\ bhuiyan.alam@utoledo.edu \\ * Correspondence: zafri@urp.buet.ac.bd
}

check for

updates

Citation: Zafri, N.M.; Khan, A.; Jamal, S.; Alam, B.M. Impacts of the COVID-19 Pandemic on Active Travel Mode Choice in Bangladesh: A Study from the Perspective of Sustainability and New Normal Situation. Sustainability 2021, 13, 6975. https:// doi.org/10.3390/su13126975

Academic Editors: Sara Moridpour and Richard Tay

Received: 5 May 2021

Accepted: 16 June 2021

Published: 21 June 2021

Publisher's Note: MDPI stays neutral with regard to jurisdictional claims in published maps and institutional affiliations.

Copyright: (c) 2021 by the authors. Licensee MDPI, Basel, Switzerland. This article is an open access article distributed under the terms and conditions of the Creative Commons Attribution (CC BY) license (https:/ / creativecommons.org/licenses/by/ $4.0 /)$.

\begin{abstract}
The COVID-19 pandemic has caused incredible impacts on people's travel behavior. Recent studies suggest that while the demand for public transport has decreased due to passengers' inability to maintain physical distance inside this mode, the demand for private automobile and active transport modes (walking and cycling) has increased during the pandemic. Policymakers should take this opportunity given by the pandemic and encourage people to use active transport more in the new normal situation to achieve sustainable transportation outcomes. This study explores the expected change in active transport mode usage in the new normal situation in Bangladesh based on the data from a questionnaire survey. The study finds that $56 \%$ and $45 \%$ of the respondents were expected to increase travel by walking and cycling, respectively, during the new normal situation. On the other hand, $19 \%$ of the respondents were expected to do the opposite. The study further identifies the factors influencing the expected change in travel by active transport modes during the new normal situation by developing multinomial logistic regression models. Finally, this study proposes policies to increase active transport use beyond the pandemic and ensure sustainable mobility for city dwellers and their well-being.
\end{abstract}

Keywords: walking; cycling; pandemic; COVID-19; new normal; sustainable transportation

\section{Background}

It has been more than a year since the first case of COVID-19 was detected in the city of Wuhan in China [1]. The pandemic has created havoc in the lives of people all around the world [2]. Thus far, the highly contagious disease has spread to 219 countries, being contracted by 140.3 million people and killing more than 3 million [3]. Apart from creating a panic in the public health arena, COVID-19 has affected many other vital sectors, including transportation [4]. COVID-19 spread from Wuhan to other countries through the transportation system, though primarily via air travel [5]. The first major step for these countries was to suspend flights and close their borders [6]. They adopted different types of lockdown measures to limit the internal spread, ranging from movement restrictions to full curfews $[7,8]$. These measures were supplemented by responsibilities imposed on individuals, such as maintaining a social distance of approximately 1-2 m, wearing a face mask in public places and sanitizing their hands $[9,10]$.

The lockdown measures were subsequently relaxed to mitigate the negative impacts on the economy [11,12]. If lockdown measures are applied for a long time, its effectiveness is likely to wane over time. The COVID-19 situation worsened in several countries due to the relaxation of restrictions, and some of the measures were reapplied in response to the second wave of infections $[13,14]$. The recent discovery of the COVID-19 vaccine brought a 
ray of hope to the people [15]. However, recent incidents related to vaccines have raised serious concerns about their success in solving the COVID-19 problem in the near future. The main vaccines which have started to be widely used are the Oxford Uni-AstraZeneca, Pfizer-BioNTech, Moderna, and Johnson \& Johnson vaccines [16]. Among these, the first three require administration in two doses, and the fourth can be administered in one. Only the Oxford Uni-AstraZeneca vaccine can be stored at a normal refrigeration temperature, while the rest are stored in temperatures between $-70{ }^{\circ} \mathrm{C}$ and $-20{ }^{\circ} \mathrm{C}$, making it the convenient choice for less-developed countries. Unfortunately, the use of this vaccine has been suspended in 17 countries and permanently halted in one country (Denmark) over possible side effects leading to blood clots $[17,18]$. Six cases of blood-clotting were also detected after administering the single-dose Johnson \& Johnson vaccine in the US, and its application has been suspended in the US, South Africa, and the European Union [16].

As of 17 April 2021, more than 878 million vaccine doses have been applied in 157 countries, which is equivalent to 11 doses per 100 people [19]. The majority of these are first doses, and from these statistics, it can be observed that only a minor portion of the global population has been vaccinated so far, and many countries have yet to begin their vaccination programs. Therefore, we might have to wait a long time for a solution to the COVID-19 problem. To eliminate the pandemic, at least $85 \%$ of people need to be vaccinated [20]. Until the world has an appropriate fix for COVID-19, individuals need to change their ways of life to carry out their activities on a full scale by embracing preventive measures to shield themselves and others from COVID-19. Contrasted with the pre-COVID-19 circumstance, this new circumstance is characterized as the 'new normal' situation in this study [21-23]. Since the 'new normal' situation is likely to be prolonged, it would be worthwhile to know how people are planning to carry out their activities and travel in this period.

At the time of writing this paper, several studies are available on the impact of COVID-19 on the transportation sector, specifically the transmission of COVID-19 through transportation [24-27], virus transmission risks in travel modes [28,29], operation and maintenance of transportation systems [30,31], public transportation [32,33], the impacts of COVID-19 on travel demand [34-36], activity patterns [37-41], and mode choice behavior [42-44] during the lockdown and post-lockdown periods. The emerging literature in the field indicates that people's travel behavior has changed in response to the threats of COVID-19's spread and related guidelines and restrictions that are still active $[38,39,41,42,45]$. The change is reflected more in the case of travel mode choice behavior. According to the initial reports and research findings, passengers perceived public transport as unsafe for traveling during the pandemic, leading to lower patronage compared with the pre-COVID-19 period [32,33,35,41]. The decline in the overall use of public transport worldwide and the loss of its modal share is a concern for transport planners. A segment of the public transport users is switching to private modes (e.g., cars and motorcycles) after the lockdown period $[41,42,46]$, which will be a setback for achieving sustainable transportation outcomes. Limited empirical evidence and information worldwide indicates that people are also resorting more to active transport since the outbreak of COVID-19 [40,41,47,48]. Measures should be in place not only to bring back the people who switched from public transport to private vehicles due to the pandemic, but also to have active transport modes capture a portion of them to prevent the rise of private modes modal shares. Otherwise, the local environmental situation and global $\mathrm{CO}_{2}$ emission problems could become worse than in the pre-pandemic era. It would be even better if some of the usual private mode travelers could be shifted to active transport modes.

Using active transport modes like walking and cycling is akin to sustainable transportation. Increased and sustained use of active transport modes would contribute to improving the air quality of the cities and the well-being of societies. Numerous research examples indicate that public health issues of cities are better addressed through the increased uptake of cycling [33,35]. During the COVID-19 pandemic, the importance of using active transport modes has grown. Unlike the trips made by public transport modes in confined spaces, active travel can be accomplished in an unconfined space. The chance of 
virus transmission is higher in a confined space [49]. A study found that out of 318 people in China with the COVID-19 virus, one contracted it outdoors, while the others contracted it indoors [50]. It is easier to maintain a physical distance of 1-2 $\mathrm{m}$ when traveling by bicycle or on foot than inside a shared vehicle [51]. Moreover, people are unlikely to catch COVID-19 by passing cyclists [52]. Outdoor travel is likely to help in the natural intake of vitamin $\mathrm{D}$, which has been strongly recommended for boosting the immune system to fight against COVID-19. One study based on the data for the first wave of COVID-19 patients admitted to hospitals found that vitamin D deficiency increased the chance of death by 3.7 times [53]. Physical exercise is also a means to strengthen the immune system to fight against COVID-19 [54]. Therefore, active transport can play a vital role in this regard as well. All these benefits of using active transport modes are likely to have increased uptake during the COVID-19 period. Government and transportation agencies invested in walking and cycling infrastructures and facilities in many countries (e.g., Italy, France, Colombia, Australia, and the UK) during the pandemic period to encourage people to travel by active transport modes $[47,55,56]$. Therefore, policymakers should take proper steps to sustain the rise of active transport use in the new normal situation and beyond.

Though there has been significant ongoing research to understand the change in mode choice behavior for COVID-19, results are still sparse. The studies have been more focused on the change in travel behavior in the short term, whereas it is also important to investigate whether there would be a change in travel behavior in the long term [38]. To the best of our knowledge, there is a lack of empirical evidence on the issues related to the impacts of the pandemic on active transport modes (walking and cycling) focusing on the 'new normal situation' throughout the world, especially in the context of a developing country like Bangladesh (or other countries in the Global South). It would be worth examining whether COVID-19 is threatening the potential growth of active transport or offers an opportunity to realize this sustainable transportation mode's potential.

A couple examples of research could be found that covered the association of COVID19 and transportation issues in Bangladesh. Among them, the one by Abdullah and Dias [44] was based on a questionnaire survey with 1203 respondents in more than 15 countries across the world, including Bangladesh. Respondents from Bangladesh constituted $14 \%$ of the total, and the survey was administered in May 2020 during a complete lockdown in the country. The study mainly aimed to find the change in travel behavior before and during COVID-19, and its results were presented in an aggregated way. The study of Anwari and Tawkir Ahmed [57] is perhaps the only one on this topic with Bangladesh as the study area. However, like the study by Abdullah and Dias [44], their online survey (a total of 572 responses) was partially administered during the lockdown (from May 2020 to June 2020). This study, like the previous one, compared the travel behavior changes before and during the COVID-19 situation. However, none of the studies attempted to capture the intended travel behavior of Bangladeshi people in the 'new normal' situation, specifically focusing on active transport modes.

This research attempts to fill these voids in knowledge. Through a questionnaire survey administered online in July and August 2020, this study investigates the expected change in the use of active transport modes in the new normal situation in Bangladesh due to the COVID-19 pandemic and identifies the factors contributing to the expected change. This research also aims to formulate policy recommendations based on empirical evidence to help policymakers tackle the urban transportation challenges in the new normal situation and beyond and promote sustainable mobility.

\section{COVID-19 Situation and the Active Transport Scenario in Bangladesh}

The first case of COVID-19 in Bangladesh was recorded on 8 March 2020, with the first death occurring ten days later [58]. As of 16 April 2021, around 0.712 million people have contracted COVID-19, resulting in more than ten thousand fatalities $[59,60]$. To tackle the pandemic's outbreak, a complete country-wide lockdown was imposed from 26 March 2020 to 30 May 2020, during which only essential travel was allowed, and offices, 
schools, and universities operated virtually in a limited form [61]. Public transportation services resumed on 1 June 2020 under some restrictions [62]. The service providers were allowed to carry passengers at $50 \%$ of the seating capacity. To compensate for the loss of revenue due to reduced passenger numbers, they were allowed to charge $60 \%$ more than the pre-COVID-19 fares. The passenger restriction was lifted on 1 September 2020, and ticket prices returned to normal levels. Though all the offices, commercial enterprises, and entertainment outlets were gradually opened, the educational institutions have remained closed (some of them operating virtually) since the outbreak.

The first doses of the Oxford Uni-AstraZeneca vaccine were administered in Bangladesh on 7 February 2021 [63]. When it seemed that the situation was improving, Bangladesh experienced the second wave of COVID-19 in mid-March 2021, which is ongoing. The second wave is having an even greater impact on people's lives. The highest number of COVID-19 cases (7626) and deaths (101) per day were recorded on 7 April 2021 and 16 April 2021, respectively $[64,65]$. In response, the government re-imposed $50 \%$ occupancy restrictions on public transport (instead of the $60 \%$ extra fare) on 7 April 2021 and a week-long strict lockdown on 14 April 2021, which was subsequently extended for another week [66,67]. All offices and shopping and entertainment centers were closed, while urban public transport services, inter-city transport services, and domestic and international flights were suspended. Kitchen markets, supermarkets, pharmacies, seaports, export-oriented factories, and emergency services were outside the purview of these restrictions [68].

One study indicated that walking increased in Bangladesh during the COVID-19 pandemic [57], but a similar statistic is not available for cycling. However, different news items point to the fact that, like many other countries, active transport modes, especially cycling, increased. Bicycle sales increased up to three times in Bangladesh [69]. Mid-range bicycles had the highest demand, and they soon became out of stock by June 2020 as a result. Many people are presumed to cycle now after switching from public transport [70]. A bike-sharing scheme-JoBike-was introduced in Dhaka and the tourist city Cox's Bazar before the pandemic [71]. The service had to be suspended during the lockdown period, but it resumed afterward and expanded to two new areas in Dhaka since then.

\section{Methodology}

\subsection{Data Collection}

We conducted an online questionnaire survey from 1 July 2020 to 31 August 2020 to collect the data for this study. Participation in the survey was voluntary. At the beginning of the survey, respondents were provided with the consent form to be informed about the study's purpose, information to be collected, the confidentiality of the information collected, and the associated risks and benefits of participating in the survey. A total of 804 people from all over Bangladesh participated in the survey. The spatial distribution of the sample over the administrative divisions of the country is presented in Figure 1. Five surveyors were employed to promote the survey through various social media pages by contacting social media groups and pages and utilizing their personal networks. Along with that, Facebook advertisements were conducted to reach a broader audience of the country. This advertisement allowed us to reach a wide range of people and helped to obtain a more diverse sample across the country. An orientation meeting for the surveyors was conducted to familiarize them with survey objectives and expected outcomes. Initially, a pilot test was conducted. Based on the feedback, some modifications were made to the final questionnaire so that the questions became more explicit to the respondents and more relevant to the Bangladeshi context.

Like many other studies conducted during the ongoing COVID-19 pandemic (e.g., [38,42,57,72]), an online survey was conducted to ensure the safety (virus transmissionrelated risks) of both the surveyors and respondents. For this same reason, the collected data were not free from selection bias, meaning the survey was only available to individuals with internet access, and those who were familiar with the online surveys were able to participate in the survey. Thus, like most online surveys, the majority of the respondents 
from this survey were young adults (Table 1). Therefore, this might have induced some limitations on the study. However, from the sample characteristics, we could conclude that we collected a sample from a diverse socioeconomic group and spatial locations to a quite good extent (Table 1).

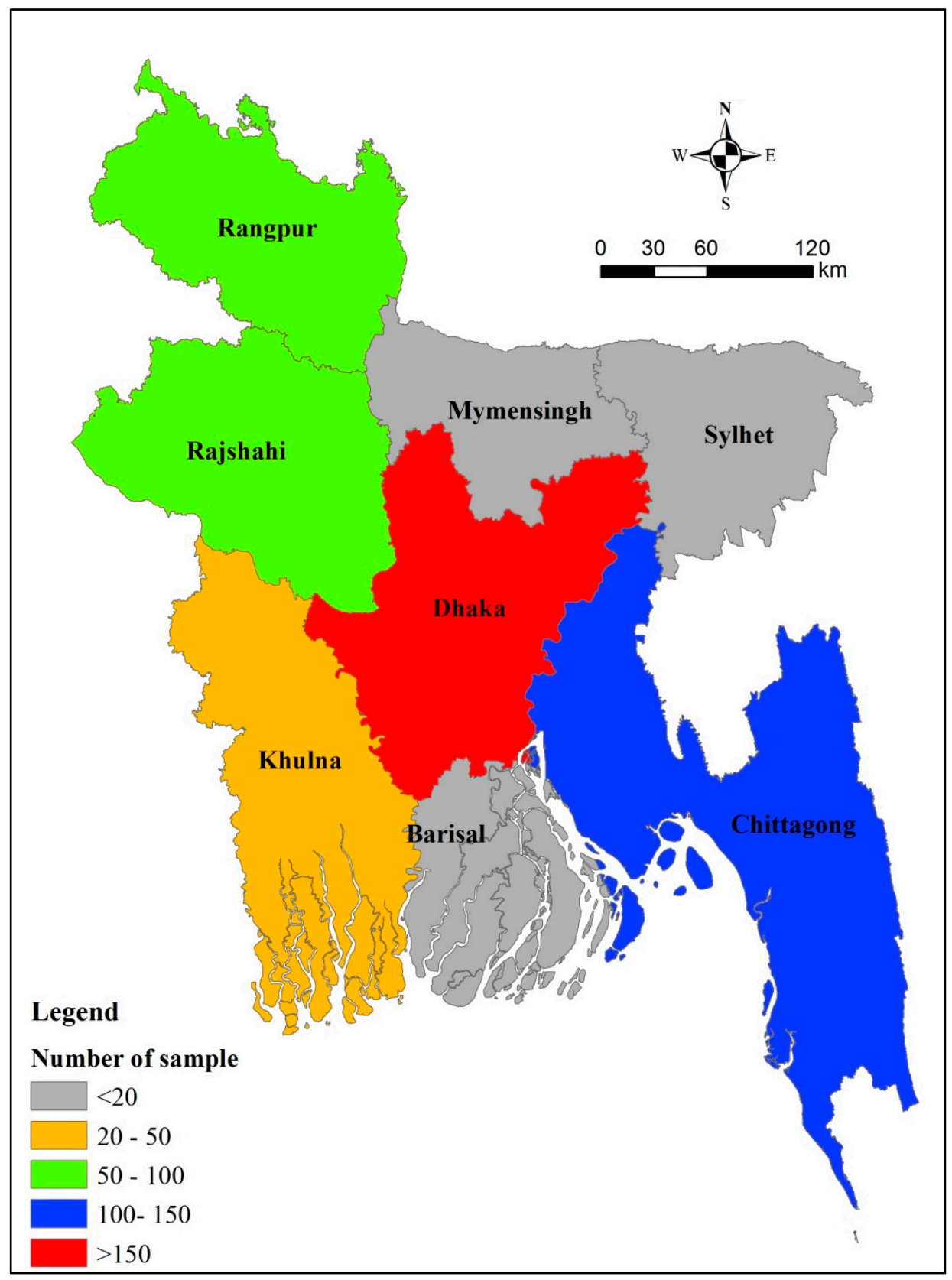

Figure 1. Map showing the spatial distribution of the sample over the administrative divisions of Bangladesh.

Through the questionnaire survey, we collected data from the respondents under six broad themes. The themes were (1) the respondents' sociodemographic characteristics, (2) pre-COVID-19 travel behavior-related factors, (3) factors related to the expected travel behavior in the new normal situation, (4) walking-specific factors, (5) cycling-specific factors, and (6) psychological factors. For collecting data on the new normal situation, we presented a hypothetical scenario to depict the new normal situation in the questionnaire. We portrayed this situation as a future situation where people adjust their lifestyles by 
adopting preventive measures to protect themselves and others from COVID-19 infections while carrying out their activities on a full scale until a proper cure or vaccine for COVID-19 is available.

Table 1. Descriptive statistics of the independent variables.

\begin{tabular}{|c|c|c|c|c|}
\hline Variable Name & Variable Description & Variable Type or Outcomes & $\%$ & Mean \\
\hline \multicolumn{5}{|c|}{ Socio-economic factors } \\
\hline \multirow{2}{*}{ Gender } & \multirow{2}{*}{ Respondent's gender } & Female & 32.96 & \\
\hline & & Male & 67.03 & \\
\hline \multirow{3}{*}{ Age group } & \multirow{3}{*}{ Respondent's age } & Young ( $<30$ years) & 83.58 & \\
\hline & & Middle-aged ( $30-60$ years) & 16.04 & \\
\hline & & Old (>60 years) & 00.37 & \\
\hline \multirow{3}{*}{ Income group } & \multirow{3}{*}{$\begin{array}{l}\text { Respondent's income group based on his or } \\
\text { her monthly household income }\end{array}$} & Low-income group $(<20,000 \mathrm{BDT})$ & 19.77 & \\
\hline & & Middle-income group $(20,000-60,000$ BDT $)$ & 55.84 & \\
\hline & & High-income group $(>60,000 \mathrm{BDT})$ & 24.37 & \\
\hline Household size & $\begin{array}{l}\text { Number of members in the } \\
\text { respondent's household }\end{array}$ & Continuous & & 4.55 \\
\hline \multirow{3}{*}{ Location } & \multirow{3}{*}{ Location of respondent's living place } & Dhaka & 45.77 & \\
\hline & & Divisional city & 18.91 & \\
\hline & & Other & 35.32 & \\
\hline \multicolumn{5}{|c|}{ Travel behavior-related factors (pre-COVID-19 and new normal situation) } \\
\hline \multirow{2}{*}{ Motorcycle ownership } & \multirow{2}{*}{$\begin{array}{l}\text { Whether respondent's household owned } \\
\text { a motorcycle }\end{array}$} & Yes & 30.50 & \\
\hline & & No & 69.50 & \\
\hline \multirow{2}{*}{ Car ownership } & \multirow{2}{*}{$\begin{array}{l}\text { Whether respondent's household owned a } \\
\text { private car }\end{array}$} & Yes & 29.70 & \\
\hline & & No & 70.30 & \\
\hline \multirow{5}{*}{$\begin{array}{l}\text { Regular pre-COVID-19 } \\
\text { travel mode }\end{array}$} & \multirow{5}{*}{$\begin{array}{l}\text { Respondent's regularly used travel mode } \\
\text { during the pre-COVID-19 situation }\end{array}$} & Public transport & 30.80 & \\
\hline & & $\begin{array}{l}\text { Shared mode (e.g., C.N.G., rickshaw, } \\
\text { and rideshare) }\end{array}$ & 26.90 & \\
\hline & & Private mode (car or motorcycle) & 20.27 & \\
\hline & & Walk & 19.50 & \\
\hline & & Bicycle & 02.49 & \\
\hline \multirow{3}{*}{$\begin{array}{l}\text { Expected change in trip } \\
\text { frequency in new normal }\end{array}$} & \multirow{3}{*}{$\begin{array}{c}\text { Expected change in the frequency of travel } \\
\text { during the new normal situation by } \\
\text { the respondent }\end{array}$} & More than pre-COVID-19 & 23.00 & \\
\hline & & Same as pre-COVID-19 & 30.00 & \\
\hline & & Less than pre-COVID-19 & 47.00 & \\
\hline \multirow{3}{*}{$\begin{array}{l}\text { Expected change in } \\
\text { virtual activities }\end{array}$} & \multirow{3}{*}{$\begin{array}{l}\text { Expected change in virtual activities (e.g., } \\
\text { online office, class, and shopping) during } \\
\text { new normal situation by the respondent }\end{array}$} & More than pre-COVID-19 & 66.00 & \\
\hline & & Same as pre-COVID-19 & 17.80 & \\
\hline & & Less than pre-COVID-19 & 16.20 & \\
\hline \multicolumn{5}{|c|}{ Walking-specific factors } \\
\hline \multirow{3}{*}{$\begin{array}{c}\text { Pre-COVID-19 } \\
\text { walking frequency }\end{array}$} & \multirow{3}{*}{$\begin{array}{l}\text { Frequency of travel by walking during } \\
\text { pre-COVID-19 situation by the respondent }\end{array}$} & Regularly (>3 days per week) & 60.57 & \\
\hline & & Usually (1-3 days per week) & 22.26 & \\
\hline & & Rarely & 17.16 & \\
\hline $\begin{array}{l}\text { Perceived risk of } \\
\text { COVID-19 transmission } \\
\text { while walking }\end{array}$ & $\begin{array}{l}\text { Respondent's perceived risk of COVID-19 } \\
\text { transmission while walking }\end{array}$ & $\begin{array}{l}\text { Five-point Likert scale }(1=\text { extremely high, } \\
\qquad 5=\text { extremely low })\end{array}$ & & 4.2 \\
\hline Walking accessibility & $\begin{array}{l}\text { Agree with the statement: "I live in a location } \\
\text { from which I can access the places of my } \\
\text { daily necessities through walking." }\end{array}$ & $\begin{array}{l}\text { Five-point Likert scale }(1=\text { strongly } \\
\quad \text { disagree, } 5=\text { strongly agree })\end{array}$ & & 2.91 \\
\hline
\end{tabular}


Table 1. Cont.

\begin{tabular}{|c|c|c|c|c|}
\hline Variable Name & Variable Description & Variable Type or Outcomes & $\%$ & Mean \\
\hline \multicolumn{5}{|c|}{ Cycling-specific factors } \\
\hline \multirow{3}{*}{$\begin{array}{l}\text { Pre-COVID-19 } \\
\text { cycling frequency }\end{array}$} & \multirow{3}{*}{$\begin{array}{l}\text { Frequency of travel by cycling during } \\
\text { pre-COVID-19 situation by the respondent }\end{array}$} & Regularly (>3 days per week) & 06.34 & \\
\hline & & Usually (1-3 days per week) & 09.45 & \\
\hline & & Rarely & 84.21 & \\
\hline \multirow{2}{*}{ Bicycle ownership } & \multirow{2}{*}{$\begin{array}{l}\text { Whether respondent's household owned } \\
\text { a bicycle }\end{array}$} & No & 67.40 & \\
\hline & & Yes & 32.60 & \\
\hline $\begin{array}{l}\text { Perceived risk of } \\
\text { COVID-19 transmission } \\
\text { while cycling }\end{array}$ & $\begin{array}{l}\text { Respondent's perceived risk of COVID-19 } \\
\text { transmission while cycling }\end{array}$ & $\begin{array}{l}\text { Five-point Likert scale }(1=\text { extremely high, } \\
\qquad 5=\text { extremely low })\end{array}$ & & 4.2 \\
\hline $\begin{array}{l}\text { Lack of supportive } \\
\text { infrastructure for cycling }\end{array}$ & $\begin{array}{l}\text { Agree with the statement: "It is difficult to } \\
\text { cycle as my area's infrastructure is not } \\
\text { supportive of bicycling". }\end{array}$ & $\begin{array}{l}\text { Five-point Likert scale }(1=\text { strongly } \\
\text { disagree, } 5=\text { strongly agree })\end{array}$ & & 3.12 \\
\hline Affordability & $\begin{array}{l}\text { Agree with the statement: "Considering my } \\
\text { current level of income and my family's } \\
\text { affordability, I can own a bicycle and use it } \\
\text { for my day-to-day travel". }\end{array}$ & $\begin{array}{l}\text { Five-point Likert scale }(1=\text { strongly } \\
\text { disagree, } 5=\text { strongly agree })\end{array}$ & & 3.56 \\
\hline Parking facility & $\begin{array}{l}\text { Agreement with the statement: "Bicycling } \\
\text { parking would be easier and cheaper". }\end{array}$ & $\begin{array}{l}\text { Five-point Likert scale }(1=\text { strongly } \\
\text { disagree, } 5=\text { strongly agree })\end{array}$ & & 3.81 \\
\hline \multirow{2}{*}{ Can ride a bicycle } & \multirow{2}{*}{ Respondent knows how to ride a bicycle } & Yes & 33.58 & \\
\hline & & No & 66.41 & \\
\hline \multicolumn{5}{|c|}{ Psychology-related variables } \\
\hline $\begin{array}{l}\text { Concern about } \\
\text { COVID-19's impact on } \\
\text { the economy }\end{array}$ & $\begin{array}{l}\text { Agree with the statement: "I am concerned } \\
\text { about the economic impacts of COVID-19 } \\
\text { in Bangladesh". }\end{array}$ & $\begin{array}{l}\text { Five-point Likert scale }(1=\text { strongly } \\
\quad \text { disagree, } 5=\text { strongly agree })\end{array}$ & & 4.08 \\
\hline $\begin{array}{l}\text { Feeling about the } \\
\text { immune system }\end{array}$ & $\begin{array}{l}\text { Agree with the statement: "I feel that my } \\
\text { immune system is very strong, and I am } \\
\text { much less likely to be affected by COVID-19". }\end{array}$ & $\begin{array}{l}\text { Five-point Likert scale }(1=\text { strongly } \\
\text { disagree, } 5=\text { strongly agree })\end{array}$ & & 2.35 \\
\hline Willingness to go outside & $\begin{array}{l}\text { Agree with the statement: "If I am allowed, I } \\
\text { am going to social gatherings to meet people } \\
\text { even if there is a risk of } \\
\text { COVID-19 transmission". }\end{array}$ & $\begin{array}{l}\text { Five-point Likert scale }(1=\text { strongly } \\
\quad \text { disagree, } 5=\text { strongly agree })\end{array}$ & & 1.85 \\
\hline $\begin{array}{l}\text { Trust in } \\
\text { preventive strategies }\end{array}$ & $\begin{array}{l}\text { Agree with the statement: "The more we take } \\
\text { precautions and follow the health guidelines, } \\
\text { the lower the risk of being affected by } \\
\text { the COVID-19". }\end{array}$ & $\begin{array}{l}\text { Five-point Likert scale }(1=\text { strongly } \\
\text { disagree, } 5=\text { strongly agree })\end{array}$ & & 4.13 \\
\hline \multirow{3}{*}{$\begin{array}{l}\text { Keeping updated } \\
\text { about COVID-19 }\end{array}$} & \multirow{3}{*}{$\begin{array}{l}\text { Respondent's keeping up to date } \\
\text { about COVID-19 }\end{array}$} & Regularly (at least one time per day) & 75.24 & \\
\hline & & Occasionally (at least one time per week) & 11.56 & \\
\hline & & Rarely & 13.18 & \\
\hline
\end{tabular}

\subsection{Data Analysis}

We applied both descriptive analysis and statistical modeling approaches to fulfill the objectives of this study. We used descriptive analysis to explore the frequency of active transport mode use before the pandemic and the expected changes in the frequency of travel by public transport, shared transport (e.g., rickshaw, auto-rickshaw or C.N.G., and ridesharing), and active transport modes during the new normal situation compared with the pre-COVID-19 situation. We developed two multinomial logistic regression models to identify the factors influencing the expected changes in travel frequency by active transport modes in the new normal situation (one model for walking and another for cycling).

Multinomial logistic regression is a popular and widely used technique for analyzing the relationship between a categorical dependent variable and multiple independent or explanatory variables through maximum likelihood estimation. This technique is generally used when the dependent variable has two or more nominal discrete outcomes [73]. If a categorical dependent variable has $k$ number of outcomes, this method will develop $k-1$ 
logistic regression models. An outcome of the dependent variable needs to be set as a reference outcome. This outcome is used to carry out a comparison with other outcomes of the dependent variable. Suppose there are three outcomes in a categorical dependent variable $(k=3): a, b$, and $c$. Here, $a$ is selected as the reference outcome. Therefore, two logistic regression models $(k=3-1=2)$ are developed through this method: the first one predicts $b$ compared with $a$, and the second one predicts $c$ compared with $a$. A generalized equation of multinomial logistic regression is presented in the following, where the outcome $I$ of the dependent variable is selected as the reference outcome:

$$
\ln \left[\frac{\pi_{i}}{\pi_{I}}\right]=\ln \left[\frac{P(y=i)}{P(y=I)}\right]=\alpha_{i}+\sum_{j-1}^{J} \beta_{i j} x_{j} ; i=1,2,3, \ldots, I-1
$$

Here, $\alpha_{i}$ is the constant and $\beta_{i j}$ is the coefficient of the $x_{j}$ independent variable for the $i$ th outcome of the dependent variable.

Our study considered "expected change in travel frequency by walking in the new normal situation" as the dependent variable, having three outcomes: less than pre-COVID19, the same as pre-COVID-19, and more than pre-COVID-19 in the first model. For the second model, we considered "expected change in travel frequency by cycling in the new normal situation" as a dependent variable having the same outcomes: less than pre-COVID19, the same as pre-COVID-19, and more than pre-COVID-19. Therefore, we found the multinomial logistic regression modeling technique suitable for identifying the factors influencing the dependent variables. We fixed the "same as pre-COVID-19" outcome of the dependent variables as the reference outcome in both models. We considered the data of the factors which were collected under the six broad themes mentioned earlier as independent variables. We did not consider walking-specific factors while developing the model for cycling or the cycling-specific factors while developing the model for walking. Details and descriptive statistics of the independent variables are presented in Table 1. For developing the model, first, we organized the dataset by cleaning and processing the collected data, as well as selecting reference outcomes and creating dummy variables of the independent variables. Then, we checked for the presence of outliers in the dataset. Finally, we developed two multinomial logistic regression models through the forward stepwise modeling technique and checked the assumptions of the model. All the analysis was performed in Statistical Package for the Social Sciences (SPSS) software.

\section{Results and Discussion}

\subsection{Impacts of COVID-19 on the Use of Active Transport Modes}

Figure 2 shows the frequency distributions of travel by active transport modes before the pandemic. Before the outbreak of COVID-19 in Bangladesh, almost 55\% of the respondents made at least one trip by walking every day (Figure 2). However, around 17\% of the respondents rarely $(13 \%)$ or never $(4 \%)$ made trips by walking. This scenario was found to be the opposite for cycling. Only a small portion of the respondents regularly traveled by cycling (4\% traveled almost every day, 3\% cycled 4-5 times a week, and 3\% cycled 2-3 times a week) during the pre-COVID-19 situation. In addition to that, about 17\% of the respondents rarely traveled by cycling, and $68 \%$ of the respondents never traveled by cycling before the arrival of the pandemic (Figure 2).

In the new normal situation, people might change their frequency of travel by different modes compared with the scenario before the pandemic. The expected change in travel frequency by public transport, shared transport, walking, and cycling by the respondents during the new normal situation is illustrated in Figure 3. The results show that about $60 \%$ and $50 \%$ of the respondents were expected to travel less by public transport and shared transport modes, respectively, during the new normal situation than in the pre-COVID-19 situation. On the other hand, about $56 \%$ of the respondents were expected to increase their travel by walking during the new normal situation, whereas this percentage was $45 \%$ for cycling (Figure 3). Around $27 \%$ and $35 \%$ of the respondents did not expect any change in 
their travel frequencies by walking or cycling, respectively. Aside from that, about $19 \%$ of the respondents were expected to decrease travel by both walking and cycling (Figure 3).

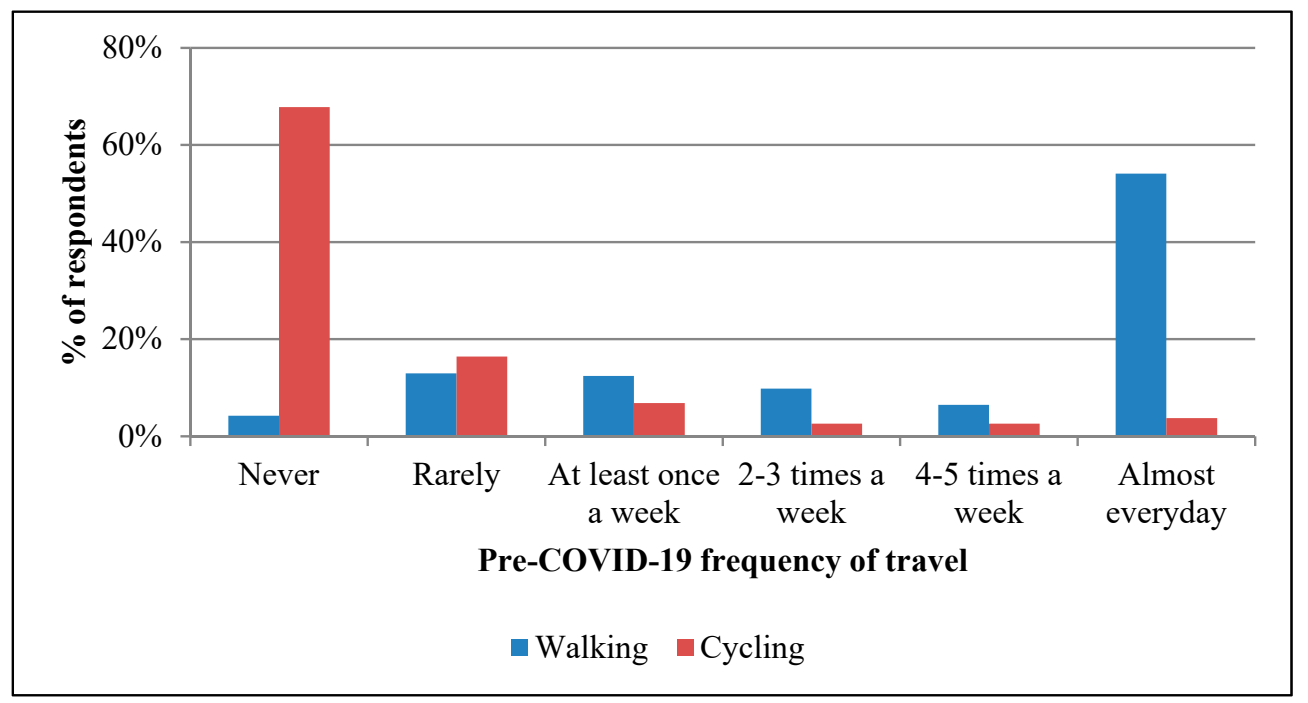

Figure 2. Frequency distribution of travel by walking and cycling before the COVID-19 pandemic.

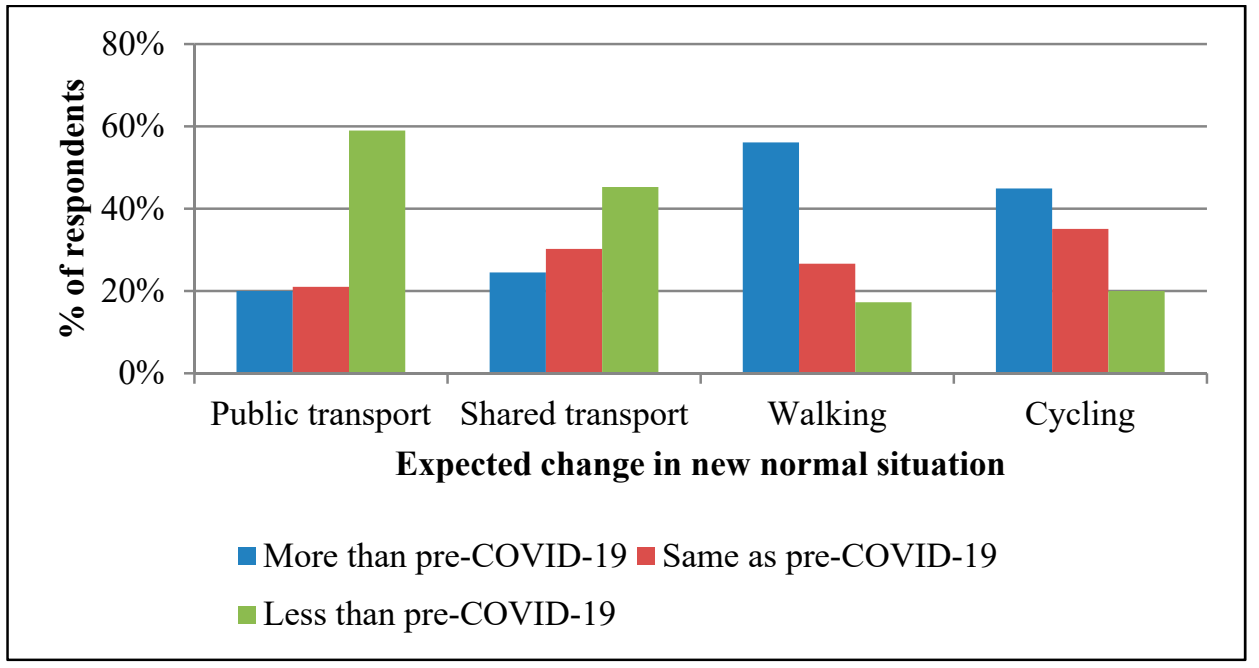

Figure 3. Expected change in the frequency of travel by public transport, shared transport, walking, and cycling during the new normal situation.

Walking is one of the major travel modes in Bangladesh. Though data for the modal share of walking is not available for the whole country, around $20 \%$ of trips are made on foot in Dhaka, according to recent studies [74,75]. This share was much higher (around 60\%) in past studies conducted in 2000 [75]. The modal share of walking shows a decreasing trend. On the other hand, cycling was neglected in Bangladesh, especially in urban areas. Cycling constitutes less than $2 \%$ of the modal share in Dhaka [76]. The results of our study also show figures similar to these statistics (Figure 2). Due to the COVID-19 pandemic, many researchers assumed that people are expected to decrease travel by public transport and shared transport modes. On the other hand, they are expected to increase travel by active transport and private modes (e.g., car or motorcycle) during the new normal situation $[46,77,78]$. These assumptions are also consistent with our study (Figure 3). A change is visible in the modal shift from public and shared transport modes to private and active transport modes. The decreasing trip share of public transport and increasing trip share of private modes will make the challenges in the transportation sector more complicated 
by increasing traffic congestion, deteriorating traffic safety, deteriorating environmental conditions (e.g., air pollution), and complicating the existing traffic management system, especially in urban areas. This move would undermine the goals of achieving a sustainable transportation system. On the other hand, increasing travel by active transport modes would help move toward sustainability.

Walking and cycling should be prioritized all over Bangladesh to utilize the opportunities created by the pandemic. This prioritization might help fine-tune the transportation system and make a visible contribution to strengthening Bangladesh's transportation system, especially in the urban areas. The average trip length by all modes in Dhaka is around $5.37 \mathrm{~km}$, while it is $8.4 \mathrm{~km}$ by bus [78]. Dhaka's average trip duration by walking is $15 \mathrm{~min}$, and the average trip length is around $1.25 \mathrm{~km}$ [79]. Although data for the average trip length by cycling in Bangladesh were not found, the range of travel by bicycle is around $15 \mathrm{~km}$ in general [80]. Therefore, a large portion of the trips is possible to be made by active transport. Therefore, it is necessary to take proper measures to increase the modal share of active transport to maximize the health, environmental, and economic benefits and reduce the congestion costs. 'Pedestrians first' is a motto universally practiced throughout the world by city authorities. In cities like Tokyo, London, Berlin, and Singapore, around 30\% of all trips are made on foot [76]. In addition to that, cycling accounts for around $10-30 \%$ of all trips in many cities, including Berlin (13\%), Shanghai (20\%), Tokyo (16\%), Beijing (32\%), and Amsterdam (28\%) [76]. Therefore, if the concerned authorities take proper steps, there is enormous potential to increase the trip share of active transport in Bangladesh during the new normal situation. This move would be helpful to achieve the goals of sustainable transportation systems in Bangladesh.

\subsection{Factors Influencing Expected Change in Frequency of Travel by Active Transport Modes}

Two multinomial logistic regression models were developed to identify the factors that could influence the expected change in travel frequency by active transport modes in the new normal situation: one for walking and the other one for cycling. Model statistics of these two models were found to be statistically significant at a $99 \%$ confidence level ( $p$-value $<0.000)$, indicating a good model fit (Table 2$)$. The pseudo R-squared $\left(\rho^{2}\right)$ values were found to be 0.257 and 0.278 for the models developed for walking and cycling, respectively, indicating that the independent variables could explain $25.7 \%$ and $27.8 \%$ of the variation in the expected change in the frequency of travel by walking and cycling during the new normal situation, respectively. The coefficient $(B)$ and odds ratio $(O R)$ statistics for the significant explanatory variables are presented in Table 2. Interpretation of the results and discussion on them are presented in the following sections.

\subsubsection{Socioeconomic Factors}

In the case of the socioeconomic factors, the respondents' income was the only factor found to be statistically significant in the model for walking. Respondents from the lowincome group were unlikely to decrease their travel frequency by walking compared with the high-income group during the new normal situation as opposed to the pre-COVID-19 situation (Table 2). The COVID-19 pandemic caused devastating impacts on the economy both in the short and long run. Due to shutdowns, lockdowns, and disastrous effects on the economy, many people lost their jobs, and a large number of small and medium business enterprises permanently closed. Therefore, the income of a considerable number of people fell [81]. Poor people's income dropped by $80 \%$ due to the pandemic in Bangladesh [82]. This poor economic condition of a large number of people might force them to travel more using affordable and economical travel modes such as public transport. However, due to the high risk of viral transmission in crowded public transport [33], they are likely to travel more by walking, an affordable and economical travel mode having a lower risk of COVID-19 transmission. 
Table 2. Results of the multinomial logistic regression models.

\begin{tabular}{|c|c|c|c|c|c|c|c|c|}
\hline \multirow[t]{3}{*}{ Factors } & \multicolumn{4}{|c|}{$\begin{array}{l}\text { Expected Change in Frequency of Travel by } \\
\text { Walking during the New Normal Situation } \\
\text { (Ref: Same as Pre-COVID-19) }\end{array}$} & \multicolumn{4}{|c|}{$\begin{array}{l}\text { Expected Change in Frequency of Travel by } \\
\text { Cycling during the New Normal Situation } \\
\text { (Ref: Same as Pre-COVID-19) }\end{array}$} \\
\hline & \multicolumn{2}{|c|}{$\begin{array}{c}\text { Less than } \\
\text { pre-COVID-19 }\end{array}$} & \multicolumn{2}{|c|}{$\begin{array}{c}\text { More than } \\
\text { pre-COVID-19 }\end{array}$} & \multicolumn{2}{|c|}{$\begin{array}{c}\text { Less than } \\
\text { pre-COVID-19 }\end{array}$} & \multicolumn{2}{|c|}{$\begin{array}{c}\text { More than } \\
\text { pre-COVID-19 }\end{array}$} \\
\hline & $B$ & OR & $B$ & OR & $B$ & OR & $B$ & OR \\
\hline Constant & -0.08 & 0.9 & -1.36 & $0.2 *$ & -1.41 & 0.2 * & -0.86 & $0.4^{* * *}$ \\
\hline \multicolumn{9}{|c|}{ Socioeconomic factor } \\
\hline \multicolumn{9}{|c|}{ Income group (Ref: High-income group) } \\
\hline Low-income group & -0.46 & $0.6^{* * *}$ & & & & & & \\
\hline \multicolumn{9}{|c|}{ Travel behavior-related factor } \\
\hline \multicolumn{9}{|c|}{ Regular pre-COVID-19 travel mode (Ref: Public transport) } \\
\hline Private mode & 0.61 & $1.9^{* *}$ & & & 0.33 & $1.4^{* * *}$ & & \\
\hline \multicolumn{9}{|c|}{ Expected change in trip frequency in the new normal situation (Ref: Same as pre-COVID-19) } \\
\hline More than pre-COVID-19 & & & 0.45 & $1.6^{* *}$ & & & 0.39 & $1.5^{* *}$ \\
\hline Less than pre-COVID-19 & 1.11 & $3.1 *$ & & & 1.40 & $4.1^{*}$ & & \\
\hline \multicolumn{9}{|c|}{ Walking-specific factor } \\
\hline \multicolumn{9}{|c|}{ Pre-COVID-19 walking frequency (Ref: Rarely) } \\
\hline Regularly & & & 0.83 & $2.3^{*}$ & & & & \\
\hline $\begin{array}{l}\text { Perceived risk of } \\
\text { COVID-19 transmission } \\
\text { while walking }\end{array}$ & -0.26 & $0.8^{*}$ & 0.17 & $1.2^{* *}$ & & & & \\
\hline
\end{tabular}

\section{Cycling-specific factor}

Pre-COVID-19 cycling frequency (Ref: Rarely)

$$
\text { Regularly }
$$

Bicycle ownership (Ref: No)

Yes

Perceived risk of

COVID-19 transmission while cycling

Lack of supportive infrastructure for cycling

\begin{tabular}{lcc}
\hline & Psychology-related factor \\
\hline $\begin{array}{c}\text { Concern about } \\
\text { COVID-19's impact on } \\
\text { the economy }\end{array}$ & 0.21 & $1.2 *$ \\
\hline $\begin{array}{c}\text { Feeling about the } \\
\text { immune system }\end{array}$ & -0.22 & $0.8^{*}$ \\
\hline Willingness to go outside & $\chi^{2}=137, d f=34, p$-value $=0.000$ & -0.19 \\
\hline $\begin{array}{l}\rho^{2}=0.257 \\
\text { Model statistics }\end{array}$ & $\begin{array}{c}\chi^{2}=176.2, d f=18, p \text {-value }=0.000 \\
\rho^{2}=0.278\end{array}$ \\
\hline
\end{tabular}

\subsection{8}

$1.6^{* *}$

0.26

$1.3 *$

$-0.15 \quad 0.8^{* *}$

* Significant at 99\% confidence level; ** Significant at 95\% confidence level; *** Significant at 90\% confidence level.

\subsubsection{Travel Behavior-Related Factor}

Among the travel behavior-related variables, regular pre-COVID-19 travel modes and the expected change in trip frequency during the new normal situation were statistically significant. The frequency of travel by walking and cycling was expected to decrease in the 
new normal situation if the respondents' regular travel mode was private (e.g., private car or motorcycle) during the pre-COVID-19 period. Respondents who regularly traveled by public transport before the COVID-19 pandemic were more unlikely to decrease their travel frequency by active transport during the new normal situation (Table 2). Previous studies assumed that private modes are relatively less risky than public transport in terms of viral transmission $[46,78,83]$. In addition, private modes are more comfortable than public transport as well as active transport, especially for long trips. In Bangladesh, transportation infrastructures are more supportive for private modes than public transport and active transport [76,84]. As a result, people using private modes regularly might not be interested in increasing their travel by active transport; instead, they might be interested in traveling even more by private modes. In the case of public transport users, a portion of them might not choose private modes for travel due to economic constraints, despite the high risk of COVID-19 transmission in public transport. Therefore, they might shift their travel mode from public transport to active transport for suitable trips. It can be deduced that a potential modal shift from public transport to private modes (e.g., cars or motorcycles) and active transport modes might happen due to the pandemic during the new normal situation. However, the modal shift from private modes to active transport is less likely. Losing the share of public transport trips, failing to attract trips by active transport, and the increasing private transport share might worsen traffic problems and undermine sustainable development goals, especially in urban areas during the new normal situation. Lastly, the results also show that respondents who anticipated an increase in their trip frequencies in the new normal situation also expected to significantly increase their travel frequency by active transport modes during that time. On the other hand, respondents who expected a decrease in trip frequencies expected to decrease their travel frequency by active transport modes (Table 2 ).

\subsubsection{Walking-Specific Factors}

From the walking-specific factors, the pre-COVID-19 walking frequency and perceived risk of COVID-19 transmission in walking were found to be statistically significant. Respondents who regularly traveled by walking before the COVID-19 pandemic were more likely to increase their travel by walking during the new normal situation than those who rarely traveled by walking. In addition to that, respondents who perceived a higher level of viral transmission risk in walking were expected to decrease travel by walking during the new normal situation. The opposite was observed if the respondents perceived a lower level of risk (Table 2). The risk perception of people was one of the most important factors which influenced their risk-taking behavior. It also dictated the adoption of certain behaviors. People engaged in less risky behavior and took more preventive measures to ensure safety from certain exposures if they perceived higher levels of risk as being associated with the exposures $[85,86]$. Hence, the frequency of travel might increase during the new normal situation if it is possible to lower the perceived risk of viral transmission by walking.

\subsubsection{Cycling-Specific Factors}

Among the cycling-specific factors, pre-COVID-19 cycling frequency, bicycle ownership, the perceived risk of COVID-19 transmission in cycling, and a lack of supportive infrastructure for cycling were found to be statistically significant in the developed model. Like in the case of walking, respondents who regularly traveled by cycling before the COVID-19 pandemic were more likely to increase their travel by this mode in the new normal situation. In addition, bicycle ownership also influenced the respondents to increase travel by cycling during the new normal situation. This was expected, as people who already own bicycles are likely to use them more than before for suitable trips previously made by public and shared transport modes, since the viral transmission risk is higher in these crowded and shared travel modes. Risk perception also played an important role in dictating the expected change in frequency of travel by cycling. The respondents were 
expected to decrease travel by cycling during the new normal situation if they perceived a higher level of viral transmission risk in cycling, and vice versa (Table 2). The results also show that the available infrastructure and facilities for cycling influenced respondents' decisions regarding cycling. The respondents were expected to travel more by cycling where supportive infrastructures were available. In Bangladesh, supportive and safe bicycle infrastructures are not available, and cycling in congested urban areas is very difficult. The concerned authorities of Bangladesh never emphasized cycling in the past, despite having many benefits associated with it. Nowadays, these authorities are aware of cycling's needs and benefits and are trying to provide some supportive infrastructures on some specific roads [74]. However, these initiatives are very limited and not enough to increase the trip share of cycling.

\subsubsection{Psychology-Related Factors}

Concern about the impacts of COVID-19 on the economy, feelings about the immune system, and the willingness to go outside were the psychology-related factors that were significant in the developed models. The results indicate that a higher level of concern about the pandemic's economic impact led to an increased likelihood of more travel by walking during the new normal situation. Previous studies showed that concern toward any apparent danger of the pandemic shapes people's decisions to adopt mitigation measures to minimize the danger $[86,87]$. Therefore, people concerned about the economic impact might have poor economic conditions, and consequently, they might try to use affordable and economical transport options like active transport. On the other hand, respondents who felt they had robust immune systems and were willing to go outside during the pandemic, undermining the risk of viral infection, were unlikely to increase travel by cycling during the new normal situation. They might have an incautious attitude and a lower perceived risk of the pandemic. Such attitudes toward the pandemic dictated for people to not take preventive measures and continue their pre-COVID-19 mode choice behaviors [87].

\section{Conclusions and Policy Recommendations}

Although COVID-19 threatens public transport's viability in most cities worldwide, it offers a unique opportunity for active transport. We feel that policymakers should take advantage of this opportunity to establish the importance of active transport for sustainable mobility and adopt measures to increase the use of active transportation modes during the new normal and COVID-19-free situations. If appropriate steps are taken soon enough, they will result in the improvement of urban air quality and mitigate the public health challenges of society, in addition to helping to negotiate climate change issues. It is a positive sign that renewed interest in active transport has been recently observed worldwide, as people perceive it to be safer than public transport regarding COVID-19 transmission. However, there is a lack of empirical evidence on the impact of COVID-19 on active transport throughout the world. This research attempted to investigate the expected change in the use of active transport modes in Bangladesh due to the COVID-19 pandemic during the new normal situation and identified the factors contributing to the expected change. The study found that people were expected to increase travel by active transport modes during the new normal situation compared with the pre-COVID-19 era. The findings also suggest that a small portion of the people expected to reduce their travel by active transport. The study further revealed that people's income, pre-COVID-19 regular travel modes, frequency of travel by active transport modes during the pre-COVID-19 situation, expected change in trip frequency during the new normal situation, risk perception, bicycle ownership, availability of supportive infrastructure in neighborhoods, concerns about the impacts of the COVID-19 pandemic on the economy, feelings about their immune systems, and willingness to go outside influenced the expected change in the frequencies of travel by active transport modes during the new normal situation. 
To encourage more people to use active transport modes, steps need to be taken as early as possible. Different countries around the world have invested in walking and cycling infrastructure to support active travel during the COVID-19 pandemic. Transport planners need to ensure that these measures are permanent. They also need to adopt additional policy measures to sustain users' interest in active transport modes beyond the pandemic and create new interest among private car users to attract them to active transport. Though complementary to each other, walking and cycling need different sets of infrastructures. Different policy issues associated with them are discussed below. The policy measures recommended in this research can be useful for other countries with similar contexts and issues.

Our study suggested that the travel frequency through walking could increase in the new normal situation. However, pedestrian facilities in Bangladesh, especially in Dhaka, are not user-friendly and safe $[88,89]$. To attract more people to travel by walking, especially for short trips, it is necessary to invest in resources to build pedestrian-friendly and aesthetically appealing roadways, as well as for routine maintenance of the pedestrian facilities. The local government authorities should arrange to have them inspected regularly. Our study also showed that private mode users were unlikely to travel by walking. However, improved facilities could attract them to traveling by walking.

A limited number of people in Bangladesh use cycling as a commuting mode. However, this study found that there is potential for cycling to cater to most urban trips if the authorities could provide the supporting infrastructure for cycling. In line with the measures in other countries where cycling is given importance, cycling should be made safer by providing dedicated cycle lanes. This will be a challenging task to implement in Dhaka, where most of the roads are already operating at their full capacity. However, it should not be too difficult to construct new lanes for cycling in other cities and towns in Bangladesh. It would be tough to justify retrofitting cycling lanes within the existing road spaces in Dhaka. However, the rickshaw is still a major mode of travel in the capital city. It would be easier to justify non-motorized transport lanes shared by bicycles and rickshaws.

The income of people, especially due to financial difficulties faced during the pandemic, was found to be an important factor in choosing a travel mode in our study. Unlike walking, cycling requires some initial investments, and the affordability to own a bicycle can be an issue for low-income people. Fifteen percent value-added tax is applicable for bicycle production, and five percent is applied for bicycle trading [90]. The import duty on the raw materials for bicycle production was recently increased from $10 \%$ to $25 \%$ [91]. There should be a tax cut on bicycle sales, and local manufacturers should manufacture bicycles of different price ranges to cater to people of different economic groups [70]. Unlike many other countries, bicycle repair costs and service availability are not issues in Bangladesh, because the rickshaw repair workshops can take care of bicycle maintenance at a low price.

The respondents were found to be concerned about their immune systems and whether they would be able to resist COVID-19 attacks. They might not know the benefits of cycling in this regard. Awareness programs should be organized to motivate people to cycle. Aside from focusing on the sustainability issues associated with cycling, its advantages during the pandemic should be highlighted. In particular, efforts should be made to lower their perceived risk of cycling. Purchasing a bicycle is the first barrier to the uptake of cycling. In Dhaka, there are quite a few leisure cycling groups. The members of these groups cycle together during the weekends. As they already own bicycles and have cycling experience in Dhaka, they would potentially be more likely to use bicycles for commuting purposes than people who have yet to own bicycles. Therefore, they should be motivated to use a cycle for commuting, and in turn, they could be used for motivating other people to start cycling.

Policies for encouraging walking and cycling are unlikely to be highly successful unless there are complementary measures for discouraging private vehicles. The discouraging measures can be applied through some taxing mechanisms. The purchase tax, road tax, fuel tax, and parking charges can be increased to make car ownership and use 
costly in order to reduce its numbers on the streets. If the modal share of active transport could be increased at the expense of private vehicles, it would pave the way for achieving sustainable transportation outcomes in the long run.

Author Contributions: Conceptualization, N.M.Z. and A.K.; data curation, N.M.Z. and S.J.; formal analysis, N.M.Z.; investigation, N.M.Z.; methodology, N.M.Z.; resources, S.J.; supervision, A.K. and B.A.; validation, S.J.; writing—original draft, N.M.Z. and A.K.; writing—review and editing, A.K., S.J. and B.A. All authors have read and agreed to the published version of the manuscript.

Funding: This research did not receive any external funds.

Institutional Review Board Statement: Not applicable.

Informed Consent Statement: Not applicable.

Data Availability Statement: Not applicable.

Acknowledgments: The research work is facilitated by the support of Bangladesh University of Engineering and Technology (BUET) through their research lab facilities and infrastructures. Hence, the authors are happy to acknowledge that support.

Conflicts of Interest: The authors declare no conflict of interest.

\section{References}

1. Jiang, F.; Deng, L.; Zhang, L.; Cai, Y.; Cheung, C.W.; Xia, Z. Review of the Clinical Characteristics of Coronavirus Disease 2019 (COVID-19). J. Gen. Intern. Med. 2020, 35, 1545-1549. [CrossRef] [PubMed]

2. Lipsitch, M.; Swerdlow, D.L.; Finelli, L. Defining the Epidemiology of Covid-19—Studies Needed. N. Engl. J. Med. 2020, 382, 1194-1196. [CrossRef]

3. Worldometer. Countries Where COVID-19 Has Spread. Coronavirus. 2021. Available online: https://www.worldometers.info/ coronavirus/countries-where-coronavirus-has-spread/ (accessed on 12 December 2020).

4. ILO. Sectoral Impact, Responses and Recommendations. COVID-19 and the World of Work 2020. Available online: https: //www.ilo.org/global/topics/coronavirus/sectoral/lang--en/index.htm (accessed on 12 December 2020).

5. Linas, B. How did coronavirus spread across the world? Why is it so bad? Massive Science, 15 March 2020.

6. Aljazeera. Coronavirus: Travel Restrictions, Border Shutdowns by Country. Tourism. 2020. Available online: https://www. aljazeera.com/news/2020/6/3/coronavirus-travel-restrictions-border-shutdowns-by-country (accessed on 12 August 2020).

7. ABC News. Victoria Records 723 New Coronavirus Cases and 13 Deaths in Pandemic's Deadliest Day. ABC News. 30 July 2020. Available online: https:/ / www.abc.net.au/news/2020-07-30/victoria-coronavirus-cases-reach-record-high/12506262 (accessed on 20 September 2020).

8. Baker, M.G.; Wilson, N.; Anglemyer, A. Successful Elimination of Covid-19 Transmission in New Zealand. N. Engl. J. Med. 2020, 383, e56. [CrossRef] [PubMed]

9. WHO. Coronavirus Disease (COVID-19) Advice for the Public. 2020. Available online: https://www.who.int/emergencies/ diseases / novel-coronavirus-2019/advice-for-public (accessed on 27 September 2020).

10. CDC. Social Distancing. Coronavirus Disease 2019 (COVID-19). 2020. Available online: https://www.cdc.gov/coronavirus/ 2019-ncov / prevent-getting-sick/social-distancing.html\#: \{\}:text=Social $\% 20$ distancing $\% 2$ C $\% 20$ also $\% 20$ called $\% 20 \%$ E2 $\% 80 \%$ 9Cphysical,both\%20indoor\%20and\%20outdoor\%20spaces (accessed on 27 September 2020).

11. Yu, X.; Qi, G.; Hu, J. Analysis of second outbreak of COVID-19 after relaxation of control measures in India. Nonlinear Dyn. 2020, 1-19. [CrossRef]

12. BBC. Coronavirus: European Countries Further Relax Restrictions. News. 18 May 2020. Available online: https://www.bbc.com/ news/world-europe-52701621 (accessed on 12 August 2020).

13. Reuters. New Travel Curbs Imposed as World Tackles Second Covid-19 Wave. The Daily Star. 27 July 2020. Available online: https: / www.thedailystar.net/coronavirus-deadly-new-threat/news/new-travel-curbs-imposed-world-tackles-secondcovid-19-wave-1937169.2020 (accessed on 26 September 2020).

14. BBC. Coronavirus: Macron Declares Second National Lockdown in France BBC News. 29 October 2020. Available online: https:/ / www.bbc.com/news/world-europe-54716993 (accessed on 11 December 2020).

15. Liu, A. Pfizer, BioNTech nab COVID-19 Vaccine Authorization from U.K. for First-Ever Marketed mRNA Shot. Fierce Pharma. 2 December 2020. Available online: https:/ / www.fiercepharma.com/vaccines/pfizer-biontech-nabs-covid-vaccine-authorizationfrom-uk-for-first-ever-marketed-mrna-shot (accessed on 10 December 2020).

16. BBC. Johnson \& Johnson Vaccine Paused over Rare Blood Clots. Coronavirus Pandemic. 14 April 2021. Available online: https:/ / www.bbc.com/news/world-us-canada-56733715 (accessed on 15 April 2021).

17. Dean, G.; Schuster-Bruce, C. Sweden Joins Germany, France, and 15 other Countries in Suspending AstraZeneca's Vaccine Over Possible Side Effects. 2021. Available online: https:/ / www.businessinsider.com/astrazeneca-covid-vaccine-countries-suspenddenmark-thailand-batch-blood-clots-2021-3?r=US\&IR=T (accessed on 15 April 2021). 
18. Peltier, E. Denmark Says It's Permanently Stopping Use of the AstraZeneca Vaccine. New York Times. 14 April 2021. Available online: https:/ /www.nytimes.com/2021/04/14/world/europe/denmark-astrazeneca-vaccine.html (accessed on 15 April 2021).

19. Holder, J. Tracking Coronavirus Vaccinations around the World. 2021. Available online: https://www.nytimes.com/interactive/ 2021/world/covid-vaccinations-tracker.html (accessed on 19 April 2021).

20. Guterl, F. The Vaccine Resistance. Newsweek, 2020.

21. Orro, A.; Novales, M.; Monteagudo, Á.; Pérez-López, J.-B.; Bugarín, M. Impact on City Bus Transit Services of the COVID-19 Lockdown and Return to the New Normal: The Case of A Coruña (Spain). Sustainability 2020, 12, 7206. [CrossRef]

22. Haque, A. Where Is the "New Normal"? The Business Standard, 8 September 2020.

23. Cahapay, M.B. Rethinking Education in the New Normal Post-COVID-19 Era: A Curriculum Studies Perspective. Aquademia Water Environ. Technol. 2020, 4, ep20018. [CrossRef]

24. Yilmazkuday, H. COVID-19 spread and inter-county travel: Daily evidence from the U.S. Transp. Res. Interdiscip. Perspect. 2020, 8, 100244. [CrossRef]

25. Zheng, R.; Xu, Y.; Wang, W.; Ning, G.; Bi, Y. Spatial transmission of COVID-19 via public and private transportation in China. Travel Med. Infect. Dis. 2020, 34, 101626. [CrossRef]

26. Shen, J.; Duan, H.; Zhang, B.; Wang, J.; Ji, J.; Wang, J.; Pan, L.; Wang, X.; Zhao, K.; Ying, B.; et al. Prevention and control of COVID-19 in public transportation: Experience from China. Environ. Pollut. 2020, 266, 115291. [CrossRef]

27. Wei, J.-T.; Liu, Y.-X.; Zhu, Y.-C.; Qian, J.; Ye, R.-Z.; Li, C.-Y.; Ji, X.-K.; Li, H.-K.; Qi, C.; Wang, Y.; et al. Impacts of transportation and meteorological factors on the transmission of COVID-19. Int. J. Hyg. Environ. Health 2020, 230, 113610. [CrossRef]

28. Truong, D.; Truong, M.D. Projecting daily travel behavior by distance during the pandemic and the spread of COVID-19 infections-Are we in a closed loop scenario? Transp. Res. Interdiscip. Perspect. 2021, 9, 100283. [CrossRef]

29. Parady, G.; Taniguchi, A.; Takami, K. Travel behavior changes during the COVID-19 pandemic in Japan: Analyzing the effects of risk perception and social influence on going-out self-restriction. Transp. Res. Interdiscip. Perspect. 2020, 7, 100181. [CrossRef]

30. Hotle, S.; Mumbower, S. The impact of COVID-19 on domestic U.S. air travel operations and commercial airport service. Transp. Res. Interdiscip. Perspect. 2021, 9, 100277. [CrossRef]

31. Sobieralski, J.B. COVID-19 and airline employment: Insights from historical uncertainty shocks to the industry. Transp. Res. Interdiscip. Perspect. 2020, 5, 100123. [CrossRef]

32. Jenelius, E.; Cebecauer, M. Impacts of COVID-19 on public transport ridership in Sweden: Analysis of ticket validations, sales and passenger counts. Transp. Res. Interdiscip. Perspect. 2020, 8, 100242. [CrossRef]

33. Tirachini, U.D.C.A. Oded Oded Cats, Delft University of Technology COVID-19 and Public Transportation: Current Assessment, Prospects, and Research Needs. J. Public Transp. 2020, 22, 1. [CrossRef]

34. Loske, D. The impact of COVID-19 on transport volume and freight capacity dynamics: An empirical analysis in German food retail logistics. Transp. Res. Interdiscip. Perspect. 2020, 6, 100165. [CrossRef]

35. Bucsky, P. Modal share changes due to COVID-19: The case of Budapest. Transp. Res. Interdiscip. Perspect. $2020,8,100141$. [CrossRef]

36. Tokey, A.I. Change of Bike-share Usage in Five Cities of United States during COVID-19. Transp. Find. 2020. [CrossRef]

37. Mogaji, E. Impact of COVID-19 on transportation in Lagos, Nigeria. Transp. Res. Interdiscip. Perspect. 2020, 6, 100154. [CrossRef]

38. Shakibaei, S.; de Jong, G.C.; Alpkökin, P.; Rashidi, T.H. Impact of the COVID-19 pandemic on travel behavior in Istanbul: A panel data analysis. Sustain. Cities Soc. 2021, 65, 102619. [CrossRef]

39. Shamshiripour, A.; Rahimi, E.; Shabanpour, R.; Mohammadian, A. (Kouros) How is COVID-19 reshaping activity-travel behavior? Evidence from a comprehensive survey in Chicago. Transp. Res. Interdiscip. Perspect. 2020, 7, 100216. [CrossRef]

40. de Haas, M.; Faber, R.; Hamersma, M. How COVID-19 and the Dutch "intelligent lockdown" change activities, work and travel behaviour: Evidence from longitudinal data in the Netherlands. Transp. Res. Interdiscip. Perspect. 2020, 6, 100150. [CrossRef]

41. Beck, M.J.; Hensher, D.A. Insights into the impact of COVID-19 on household travel and activities in Australia-The early days of easing restrictions. Transp. Policy 2020, 99, 95-119. [CrossRef] [PubMed]

42. Bhaduri, E.; Manoj, B.; Wadud, Z.; Goswami, A.K.; Choudhury, C.F. Modelling the effects of COVID-19 on travel mode choice behaviour in India. Transp. Res. Interdiscip. Perspect. 2020, 8, 100273. [CrossRef]

43. Padmanabhan, V.; Penmetsa, P.; Li, X.; Dhondia, F.; Dhondia, S.; Parrish, A. COVID-19 effects on shared-biking in New York, Boston, and Chicago. Transp. Res. Interdiscip. Perspect. 2021, 9, 100282. [CrossRef] [PubMed]

44. Abdullah, M.; Dias, C.; Muley, D. Shahin Exploring the impacts of COVID-19 on travel behavior and mode preferences. Transp. Res. Interdiscip. Perspect. 2020, 8, 100255. [CrossRef]

45. Molloy, J.; Tchervenkov, C.; Hintermann, B.; Axhausen, K.W. Tracing the Sars-CoV-2 Impact: The First Month in Switzerland. Transp. Find. 2020. [CrossRef]

46. De Vos, J. The effect of COVID-19 and subsequent social distancing on travel behavior. Transp. Res. Interdiscip. Perspect. 2020, 5, 100121. [CrossRef]

47. Davies, N.; Sherriff, G. How major cities are trying to keep people walking and cycling after the lockdown. World Economic Forum. 14 May 2020. Available online: https://www.weforum.org/agenda/2020/05/cities-support-people-walking-and-cycling-work/ (accessed on 1 June 2020).

48. Hadjidemetriou, G.M.; Sasidharan, M.; Kouyialis, G.; Parlikad, A.K. The impact of government measures and human mobility trend on COVID-19 related deaths in the UK. Transp. Res. Interdiscip. Perspect. 2020, 6, 100167. [CrossRef] 
49. Dai, H.; Zhao, B. Association of the infection probability of COVID-19 with ventilation rates in confined spaces. Build. Simul. 2020, 13, 1321-1327. [CrossRef] [PubMed]

50. Qian, H.; Miao, T.; Liu, L.; Zheng, X.; Luo, D.; Li, Y. Indoor transmission of SARS-CoV-2. Indoor Air 2021, 31, 639-645. [CrossRef] [PubMed]

51. Brooks, J.H.M.; Tingay, R.; Varney, J. Social distancing and COVID-19: An unprecedented active transport public health opportunity. Br. J. Sports Med. 2020, 2020, 102856. [CrossRef]

52. Samuel, S. Why You're Unlikely to Get the Coronavirus from Runners or Cyclists. 2020. Available online: https://www.vox.com/ future-perfect/2020/4/24/21233226/coronavirus-runners-cyclists-airborne-infectious-dose (accessed on 30 November 2020).

53. McCall, B. Vitamin D Deficiency in COVID-19 Quadrupled Death Rate. Medscape (11 December 2020) 2020. Available online: https:/ / www.medscape.com/viewarticle/942497 (accessed on 12 December 2020).

54. Da Silveira, M.P.; Fagundes, K.K.D.S.; Bizuti, M.R.; Starck, É.; Rossi, R.C.; Silva, D.T.D.R.E. Physical exercise as a tool to help the immune system against COVID-19: An integrative review of the current literature. Clin. Exp. Med. 2020. [CrossRef]

55. Schulz, F. Bikes starting to push cars out of cities thanks to COVID-19. Euractive. 8 May 2020. Available online: https: //www.euractiv.com/section/future-of-mobility/news/bikes-starting-to-push-cars-out-of-cities-thanks-to-covid-19/ (accessed on 31 May 2021).

56. Jacks, T. Car parks out, footpaths and cycling lanes in as city prepares for post-COVID commuters. The Age, 7 May 2020.

57. Anwari, N.; Ahmed, T.; Islam, R.; Hadiuzzaman; Amin, S. Exploring the travel behavior changes caused by the COVID-19 crisis: A case study for a developing country. Transp. Res. Interdiscip. Perspect. 2021, 9, 100334. [CrossRef]

58. The Business Standard. First coronavirus cases detected in Bangladesh. Health. 8 March 2020. Available online: https: / / tbsnews.net/bangladesh/health/3-tested-positive-coronavirus-bangladesh-iedcr-53476 (accessed on 26 September 2020).

59. GoB. Corona Virus Update in Bangladesh. Corona Info. 12 December 2020. Available online: https://corona.gov.bd/.2020 (accessed on 12 December 2020).

60. GoB. Latest Status in Bangladesh. 2021. Available online: https://corona.gov.bd/ (accessed on 17 April 2021).

61. Medicalxpress. Bangladesh Lifts Virus Lockdown, Logs Record Deaths on Same Day. Diseases, Conditions, Syndromes. 31 May 2020. Available online: https:/ / medicalxpress.com/news/2020-05-bangladesh-virus-lockdown-deaths-day.html (accessed on 30 June 2020).

62. The Daily Star. Public Transport: Pre-Covid fare, health rules not followed. The Daily Star. 2 September 2020. Available online: https://www.thedailystar.net/frontpage/news/public-transport-pre-covid-fare-health-rules-not-followed-1954377 (accessed on 27 September 2020).

63. Sakib, S.M.N. Bangladesh president gets 1st dose of COVID-19 vaccine. AA. 10 March 2021. Available online: https://www.aa. com.tr/en/asia-pacific/bangladesh-president-gets-1st-dose-of-covid-19-vaccine/2171569 (accessed on 15 April 2021).

64. Prothom Alo. Bangladesh reports record 7626 cases, 63 deaths in 24 hrs. Covid-19. 7 April 2021. Available online: https: / / en.prothomalo.com/bangladesh/bangladesh-reports-record-7626-cases-63-deaths-in-24-hrs (accessed on 15 April 2021).

65. Dhaka Tribune. Covid-19: Bangladesh shatters record again as 101 deaths reported in 24 hours. Coronavirus. 16 April 2021. Available online: https://www.dhakatribune.com/health/coronavirus/2021/04/16/covid-19-bangladesh-reports-101-deathsas-record-breaking-surge-continues (accessed on 19 April 2021).

66. The Daily Star. "Lockdown": Public transport services to resume tomorrow in 11 major cities. Coronavirus. 6 April 2021. Available online: https: / / www.thedailystar.net/coronavirus-deadly-new-threat/news/govt-decides-resume-public-transport-servicesdivisional-cities-amid-restrictions-2073121 (accessed on 15 April 2021).

67. Bhattacharjee, P.P.; Adhikary, T.S. Extended lockdown to be stricter. The Daily Star. 10 April 2021. Available online: https: //www.thedailystar.net/frontpage/news/extended-lockdown-be-stricter-2079729 (accessed on 19 April 2021).

68. BD News. Bangladesh to shut all offices, public transports in new lockdown rules. Bangladesh. 12 April 2021. Available online: https:/ /bdnews24.com/bangladesh/2021/04/12/bangladesh-to-shut-all-offices-public-transports-in-new-lockdownrules (accessed on 15 April 2021).

69. Aljazeera. Coronavirus fuels bicycle sales in congested Bangladesh cities. Coronavirus Pandemic. 19 June 2020. Available online: https: / / www.aljazeera.com/news / 2020/6/19/coronavirus-fuels-bicycle-sales-in-congested-bangladesh-cities (accessed on 28 August 2020).

70. Bhuiyan, A.H. Demand for bicycles grows amid COVID-19 pandemic. The Financial Express. 5 June 2020. Available online: https:/ / thefinancialexpress.com.bd/trade/demand-for-bicycles-grows-amid-covid-19-pandemic-1591330805 (accessed on 10 June 2020).

71. Billah, M. Pandemic-hit JoBike sees opportunity in adversity. The Business Standard. 5 November 2020. Available online: https: //tbsnews.net/feature/panorama/pandemic-hit-jobike-sees-opportunity-adversity-153628 (accessed on 6 November 2020).

72. Dong, E.; Du, H.; Gardner, L. An interactive web-based dashboard to track COVID-19 in real time. Lancet Infect. Dis. 2020, 20, 533-534. [CrossRef]

73. Kwak, C.; Clayton-Matthews, A. Multinomial Logistic Regression. Nurs. Res. 2002, 51, 404-410. [CrossRef]

74. RAJUK. Dhaka Structure Plan 2016-2035; RAJUK: Dhaka, Bangladesh, 2015.

75. Hoque, M.M.; Ahsan, H.M.; Barua, S.; Alam, D. BRT in Metro Dhaka: Towards achieving a sustainable urban public transport system. In Proceedings of the Conference CODATU XV, Addis Ababa, Ethiopia, 22-25 October 2012; pp. 1-11.

76. Gallagher, R. Prioritising Dhaka's Urban Transport System. J. Bus. Technol. 2017, 11, 141-144. [CrossRef] 
77. Budd, L.; Ison, S. Responsible Transport: A post-COVID agenda for transport policy and practice. Transp. Res. Interdiscip. Perspect. 2020, 6, 100151. [CrossRef]

78. Rahman, M.S. The Only Solution. Forum 2010, 3, 3.

79. Sharmeen, N.; Houston, D. Spatial Characteristics and Activity Space Pattern Analysis of Dhaka City, Bangladesh. Urban Sci. 2019, 3, 36. [CrossRef]

80. Gallagher, R. Dhaka's Future Urban Transport: Costs and Benefits of Investment in Public and Private Transport; Copenhagen Consensus Center: Copenhagen, Denmark, 2016.

81. Doza, B.-; Shammi, M.; Bahlman, L.; Islam, A.R.M.T.; Rahman, M. Psychosocial and Socio-Economic Crisis in Bangladesh Due to COVID-19 Pandemic: A Perception-Based Assessment. Front. Public Health 2020, 8, 341. [CrossRef]

82. Bhuiyan, A.K.M.I.; Sakib, N.; Pakpour, A.H.; Griffiths, M.D.; Mamun, M.A. COVID-19-Related Suicides in Bangladesh Due to Lockdown and Economic Factors: Case Study Evidence from Media Reports. Int. J. Ment. Heal Addict. 2020. [CrossRef]

83. Troko, J.; Myles, P.; Gibson, J.; Hashim, A.; Enstone, J.; Kingdon, S.; Packham, C.; Amin, S.; Hayward, A.; Van-Tam, J.N. Is public transport a risk factor for acute respiratory infection? BMC Infect. Dis. 2011, 11, 16. [CrossRef] [PubMed]

84. JICA. Preparatory Survey Report on Dhaka Urban Transport Network Development Study (DHUTS) in Bangladesh; JICA: Tokyo, Japan, 2010.

85. Dryhurst, S.; Schneider, C.R.; Kerr, J.; Freeman, A.L.J.; Recchia, G.; van der Bles, A.M.; Spiegelhalter, D.; van der Linden, S. Risk perceptions of COVID-19 around the world. J. Risk Res. 2020, 23, 994-1006. [CrossRef]

86. He, S.; Chen, S.; Kong, L.; Liu, W. Analysis of Risk Perceptions and Related Factors Concerning COVID-19 Epidemic in Chongqing, China. J. Community Health 2021, 46, 278-285. [CrossRef] [PubMed]

87. Khosravi, M. Perceived Risk of COVID-19 Pandemic: The Role of Public Worry and Trust. Electron. J. Gen. Med. 2020, 17, em203. [CrossRef]

88. Pervaz, S.; Newaz, K.M.S. Pedestrian safety at intersections in Dhaka metropolitan city. In Proceedings of the 17th International Conference Road Safety on Five Continents (RS5C 2016), Rio de Janeiro, Brazil, 17-18 May 2016.

89. Saha, M.K.; Rahman, T.; Islam, M.S.; Mitra, S.K. Pedestrian behavioral pattern and preferences in different road crossing systems of Dhaka city. J. Bangladesh Inst. Plan. 2013, 6, 149-160.

90. Tribune Desk. NBR finds Bangshal cycle maker evaded VAT of Tk 54cr. Dhaka Tribune. 2 December 2020. Available online: https: / / www.dhakatribune.com/business/2020/12/02/nbr-finds-bangshal-cycle-maker-evaded-vat-of-tk-54cr (accessed on 6 December 2020).

91. LCAW, Bicycle Industry in Bangladesh: Pedalling into Global Market, in DATAB. Available online: https://databd.co/stories/ bicycle-industry-in-bangladesh-pedalling-into-global-market-9842\#: \{\{\}:text=Persistence\%20Market\%20Research\%20(PMR) \%20report,reach\%20USD \%2062bn \%20by\%202024.\&text=According\%20to\%20Eurostat \%2C\%20Bangladesh \%20is, exporter\%20 in\%20the\%20global\%20market (accessed on 6 December 2020). 